\title{
Multiple Linear Regression Modelling for Predicting Building's Short Columns Loads under Gravity
}

\author{
Mohanad Y. Abdulwahid ${ }^{1}$, Tamer Haddad ${ }^{2}$, Hend Tubaila ${ }^{3}$ and Imad A. Al-Qasem ${ }^{4}$ \\ ${ }^{1}$ Lecturer, Civil Engineering Department, Koya University, Koya KOY45, Kurdistan Region - F.R. Iraq. \\ ${ }^{2}$ Instructor, Industrial Engineering Department, An-Najah National University, Nablus, Palestine. \\ ${ }^{3}$ Instructor, Civil Engineering Department, An-Najah National University, Nablus, Palestine. \\ ${ }^{4}$ Lecturer, Civil Engineering Department, An-Najah National University, Nablus, Palestine. \\ ORCIDs: 0000-0002-9574-543X (Mohanad), 0000-0002-9574-543X (Tamer) \\ 0000-0002-1071-0220 (Hend), 0000-0001-8356-7755 (Imad)
}

\begin{abstract}
This research is an attempt to understand and model the performance of short columns under different ground levels and storey number. This behaviour includes varying axial forced, shear forces, and bending moments under gravity loads. All the results have been taken for the columns at the ground level when the phenomenon of the short column has appeared. To study the performance of short columns under different ground levels and the number of stories, the 3D finite element by sap2000, and multiple linear regression analysis have been used in this study. The results show that the axial force for all types of short columns (internal, edge, corner) increases as the number of stories in the building increases at the same ground level. The effect of changing the number of floors with the same value of ground level is not significant in shear and moment for all types of columns except for the one-story and two-storey buildings. For more illustration, the moment and shear for a building composed of one story is very high compared to the two-storey building where the value becomes significantly low; then become higher again with a 3-storey building and with more stories.
\end{abstract}

Keywords: Axial force, Bending Moment, Ground Level, Multiple Linear Regression, Shear Force, Short column.

\section{INTRODUCTION \& RELATED WORK}

Rapid urbanization and scarcity of flat land in hilly areas are forcing people to involve in heavy constructions on hill slopes. In many cases, hilly areas of cities with attractive views represent luxurious conditions for housing development. Despite unfavourable conditions, densely located low- to medium-rise buildings are being constructed, resulting in increasing loads on slopes [1]. While designing, it must be noticed that structures on inclines are not the same as those in plain land, i.e. they are exceptionally unpredictable and unsymmetrical in flat and vertical planes Such buildings have mass and stiffness varying along the vertical and horizontal planes; as a result, the centre of mass and centre of rigidity do not coincide on various floors and twisting of structures takes place [2]. Thus, the risk factor of those irregular structures increases abruptly as even the base of those structures becomes inclined at slope [3].
A column can be defined as a vertical structural member that carries loads mainly in compression. The gravity loads (won weight and dead load) transfer from slabs and beams to the column. The majority of reinforced concrete columns are subjected to primary stresses caused by flexure, axial force, and shear. Secondary stresses associated with deformations are usually very small in most columns used in practice. Column is the main part of a structure. A beam failure would normally affect only a local region, whereas a column failure could result in the collapse of the entire structure [4].

Based on the slenderness ratio, (effective length least lateral dimension), columns can be classified into the long column and short columns. The effect of short columns is often overlooked in the design and construction of the buildings. The short column effect can either result from partial height infill walls, the addition of an extra connection beam to support a staircase, or from sloping ground [5]. Reinforced concrete (RC) members in concrete buildings are typically subjected to a combination of bending, shear and axial. For instance, the side columns on the windward side of a frame under wind load are under bending, shear and axial tension; the columns on the other side are subjected to bending, shear and axial compression.

The interactions among these three loading types must be considered because they can induce a complex stress state when applied simultaneously to a structural element [6].From a safety point of view it is important that a RC structure especially its connections should have an adequate level of integrity and high carrying load capacity, in order to produce ductile behaviour that allows distribution of forces under expected loads and redistribution of forces after unexpected events, such as the loss of a ground column. For a robust RC building, local failure shouldn't lead to total collapse of the structure [7]. The structural investigation of multi-storey building on hill slopes is attracted by many engineering researchers and designers. Most of these studies investigated the effect of slope angle variation for the structures resting on sloping ground under the seismic condition. Ramin and Mehrabpour [8] found that in short columns under earthquake, because of their shorter height, a considerable increase in stiffness of their section is observed while the percentage of shear force absorption and bending moment rises. Singh et al [9] concluded that under along-slope excitation, the varying heights of columns cause 
International Journal of Engineering Research and Technology. ISSN 0974-3154, Volume 13, Number 7 (2020), pp. 1671-1685

(C) International Research Publication House. https://dx.doi.org/10.37624/IJERT/13.7.2020.1671-1685

stiffness irregularity, and the short columns resist almost the entire storey shear. The linear and non-linear dynamic analysis shows that the storey at road level, in case of downhill buildings, is most susceptible to damage. Mohammad et al. [10] presented a parametric study involving the plan aspect ratio of stepback and stepback-setback configurations subjected to seismic load in along and across hill slope direction. All the models are geometrically modelled and analyzed with a finite element code incorporating equivalent static and response spectrum method. It was observed that the upper most storey were subjected to larger shear forces than the rest storeys. Further, stepback-setback configuration showed $45 \%$ reduction in the base shear, when compared with stepback configuration buildings and experienced lesser torsional moments and seismic forces. The sloping ground also results in presence of short columns that are susceptible to shear failure. To capture this failure, shear springs capable of simulating direct shear failure and flexure shear failure are provided on top of short columns.

In general, the short columns of hill buildings attract more forces and undergo extensive damage if it is not properly designed for earthquake forces. The using of 3D finite element models to investigate the behaviour reinforced concrete and steel structures have been the subject of many studies in the last years [11-14]. The finite element analysis of reinforced concrete (RC) structures under different conditions can be a powerful tool for predicting their behaviour in order to evaluate the safety levels of design. On the other hand, regression techniques are sometimes used for managed complicated prediction and classification problems in civil engineering [15, $16,17,18,19$, and 20].

\section{METHOD}

This paper studied and modelled the behaviour of short columns under a different number of storey and ground levels using least squared multiple linear regression to construct the appropriate models using 0.05 level of significance. The behaviour includes the variation of a variation of axial force, shear force, and bending moment of the different positions of columns. The 3D finite element model by SAP2000 was used to achieve the requirement.

\section{II.I Structural Description Model}

The proposed structures models are 50 reinforced concrete building with different storey from 1 to 10 and different ground level und $0,1,2,3,4 \mathrm{~m}$. 3D analyses are performed by using SAP2000 software. The building main data parameters related to the model is given in Table $1 \&$ Figure $1(\mathrm{a}, \mathrm{b}$ and $\mathrm{c}$ )

Table 1 Building data

\begin{tabular}{|c|c|}
\hline Type of structure & Residential building \\
\hline Plan dimensions & $18 \mathrm{~m} \times 18 \mathrm{~m}$ \\
\hline Storey height (except first storey) & $3 \mathrm{~m}$ \\
\hline Size of beams & $300 \mathrm{~mm} \times 600 \mathrm{~mm}$ \\
\hline Size of columns & $600 \mathrm{~mm} \times 600 \mathrm{~mm}$ \\
\hline
\end{tabular}

\begin{tabular}{|c|c|}
\hline Thickness of slab & $250 \mathrm{~mm}$ \\
\hline Dead load & $\begin{array}{c}3 \mathrm{kN} / \mathrm{m}^{2}+\text { own } \\
\text { weight }\end{array}$ \\
\hline Dead load & $5 \mathrm{kN} / \mathrm{m}^{2}$ \\
\hline Support type & Fixed \\
\hline Modulus of elasticity of concrete, $\mathrm{E}_{\mathrm{c}}$ & $2 \times 10^{5} \mathrm{MPa}$ \\
\hline Compressive strength of concrete, f'c & $25 \mathrm{MPa}$ \\
\hline
\end{tabular}

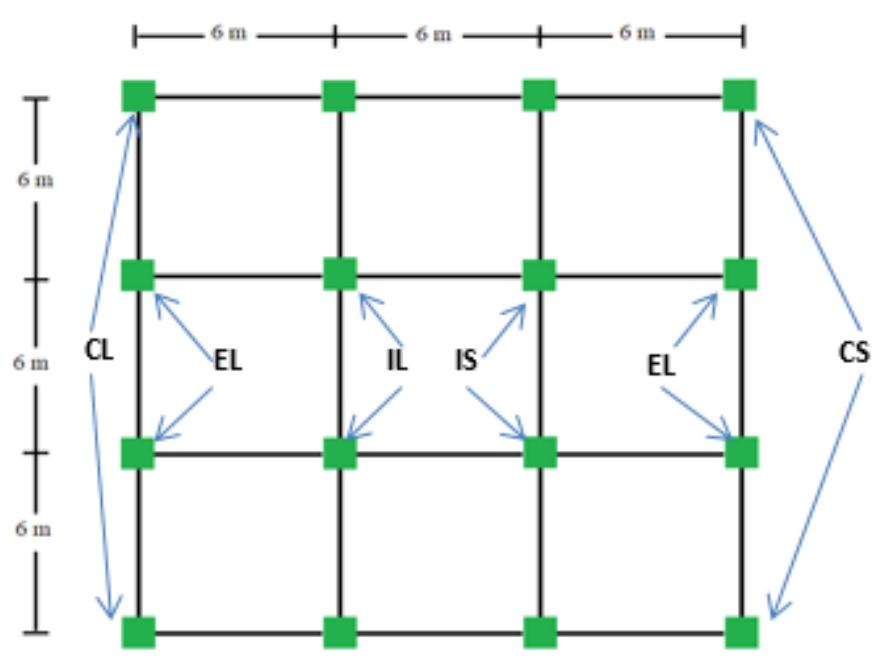

Fig. 1.a Plan of building

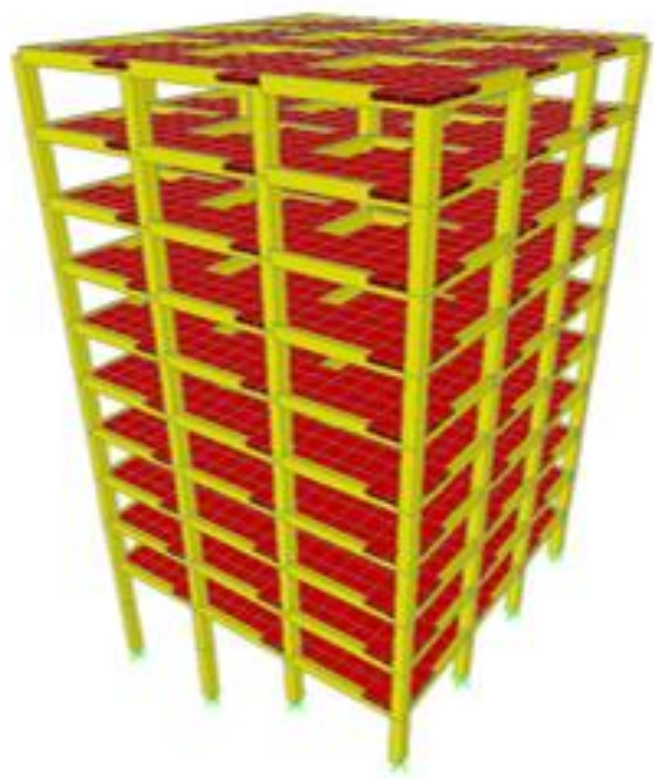

Fig. 1.b 3D view of Typical multi storey building 


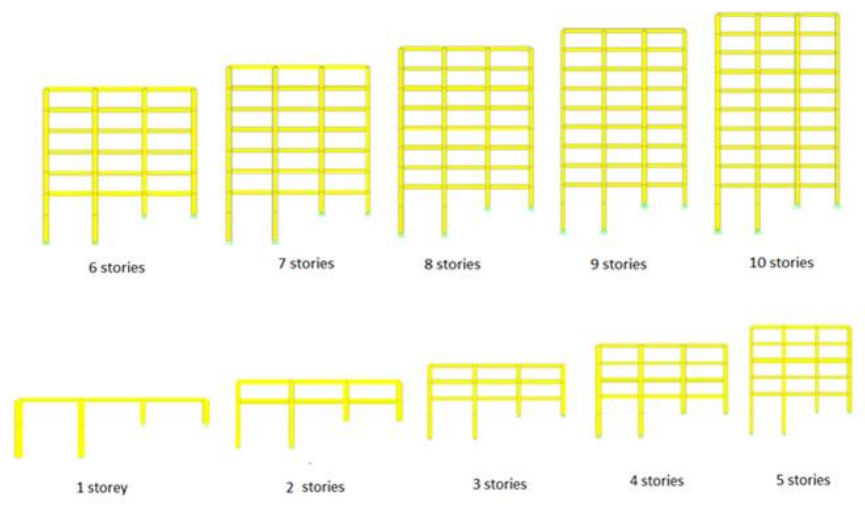

Fig. 1.c Different multi storey buildings at $4 \mathrm{~m}$ ground level

\section{II.II Regression Analysis}

Multiple linear regression analysis is a statistical method that used to correlates the behaviour or variation of number of storey and footing level, in order to ascertain their individual and combined impact upon loads under study (axial, shear and moment). This analysis was performed using least squares method for axial forces on both short and long edge, internal and edge columns. Whereas moment and shear forces analysis were analyzed on short edge, internal, and corner columns of the building under study. Before fitting models, 3D graphical plots were constructed to check if there is indeed a relationship between the number of storey, the footing level and the force under consideration. These plots are shown in figures (2 and 3 ) below.

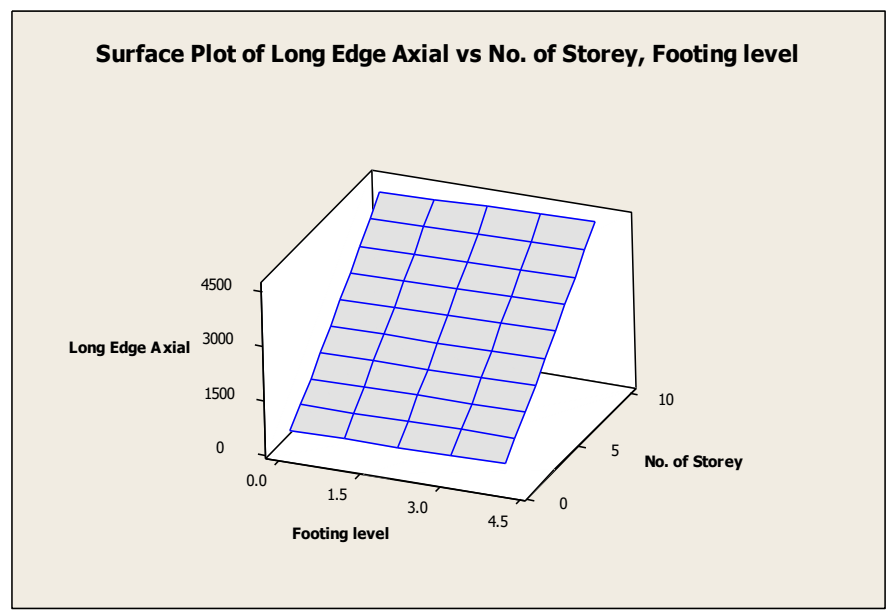

a) Axial in edge long column

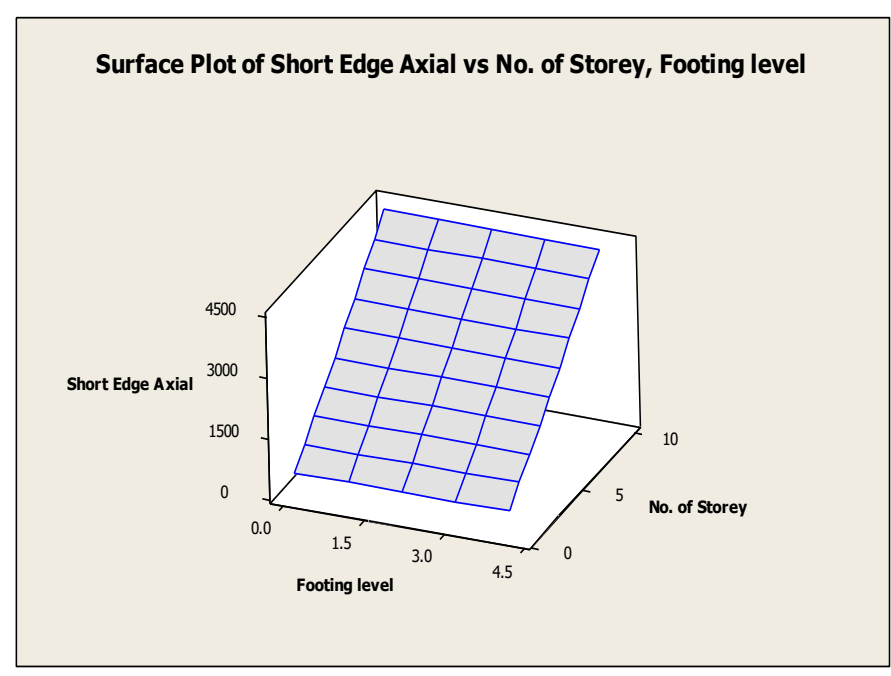

b) Axial in edge short column

Surface Plot of Long Internal Axial vs No. of Storey, Footing level

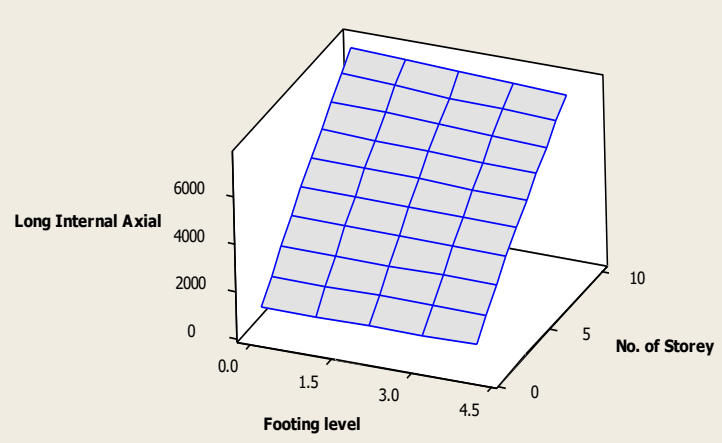

c) Axial in internal long column

Surface Plot of Axial Corner Long vs No. of Storey, Footing level

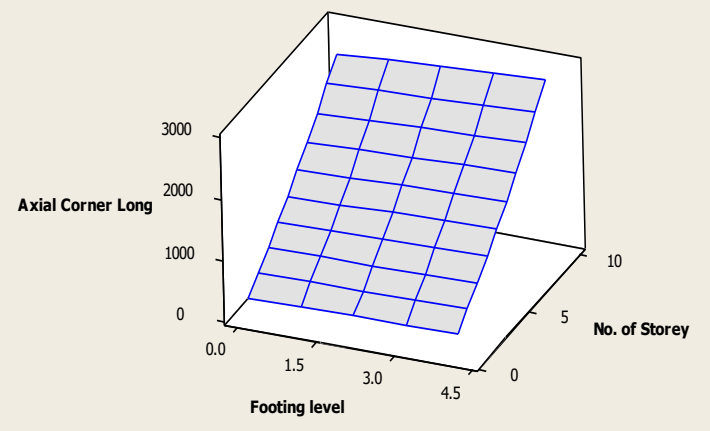

d) Axial in corner long column 
International Journal of Engineering Research and Technology. ISSN 0974-3154, Volume 13, Number 7 (2020), pp. 1671-1685

(C) International Research Publication House. https://dx.doi.org/10.37624/IJERT/13.7.2020.1671-1685

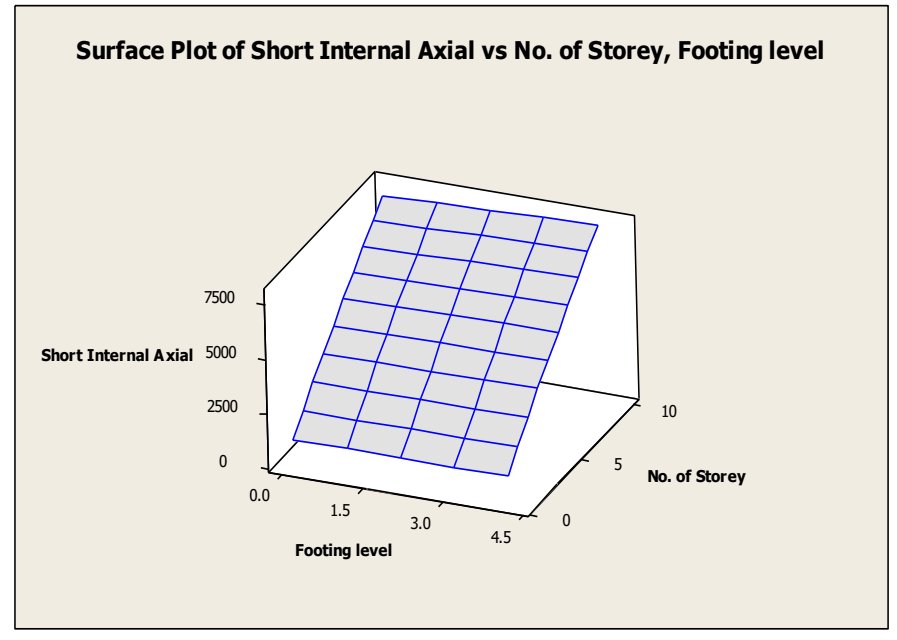

e) Axial in internal short column

\section{Surface Plot of Axial Corner Short vs No. of Storey, Footing level}

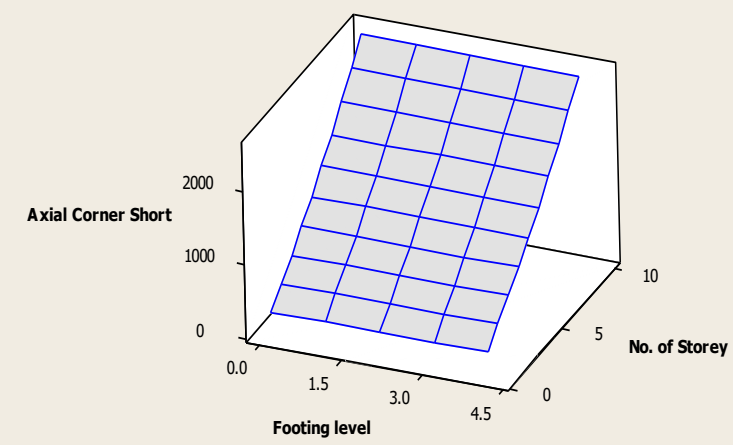

f) Axial in corner short column

Fig. 2 Axial forces in columns.

Surface Plot of Moment Edge Short vs No. of Storey, Footing level

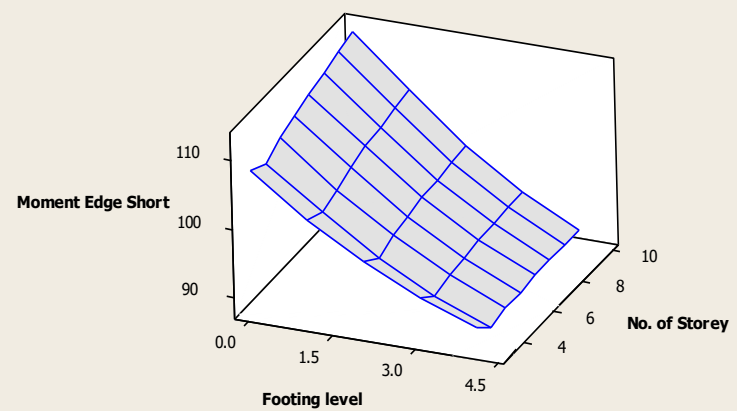

a) Moment in edge short column

\section{Surface Plot of Moment Internal Short vs No. of Storey, Footing level}

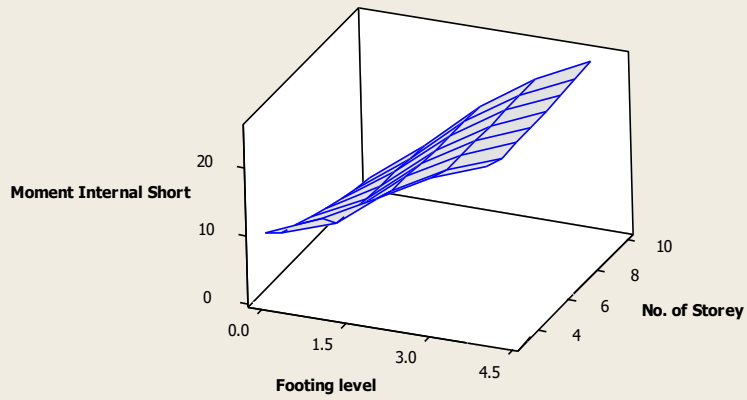

b) Moment in internal short column

Surface Plot of Moment Corner Short vs No. of Storey, Footing level

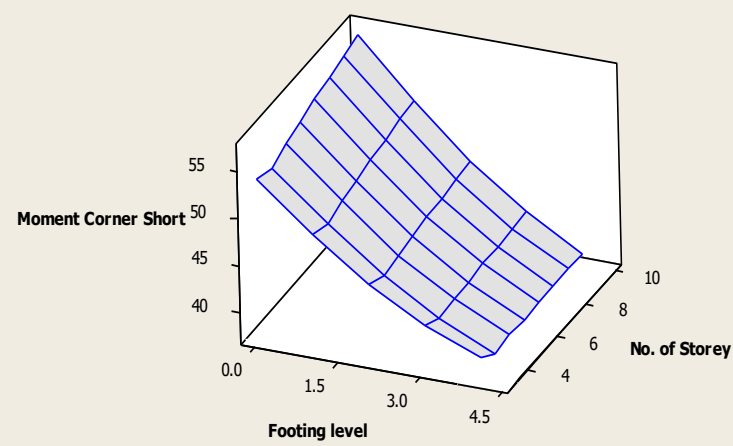

c) Moment in corner short column

Surface Plot of Edge Short Shear vs No. of Storey, Footing Level

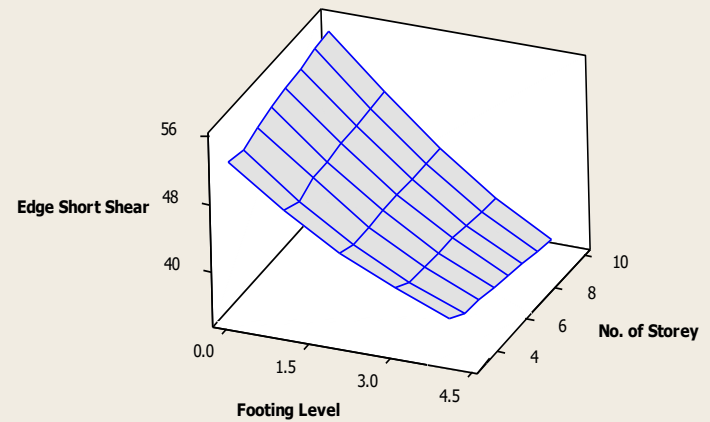

d) Shear in edge short column 


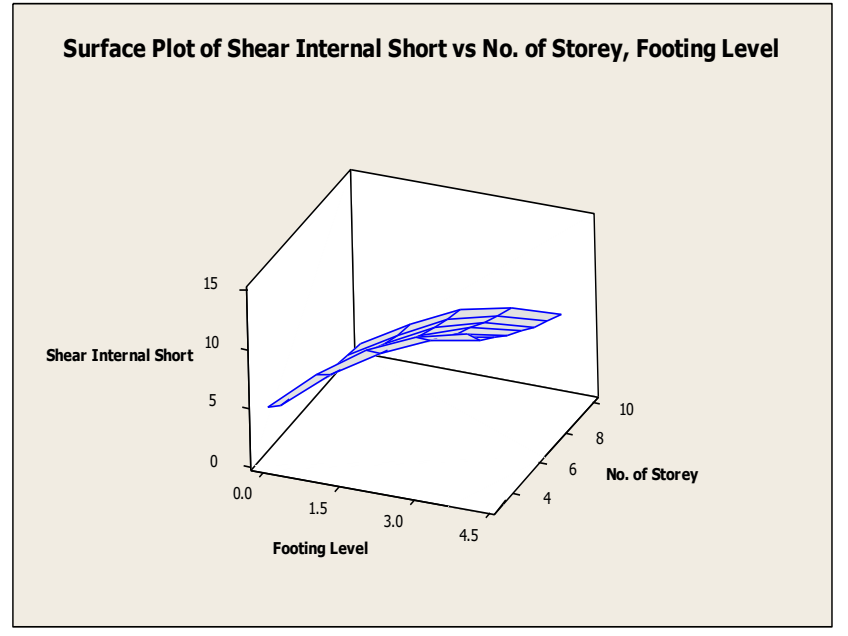

e) Shear in internal short column

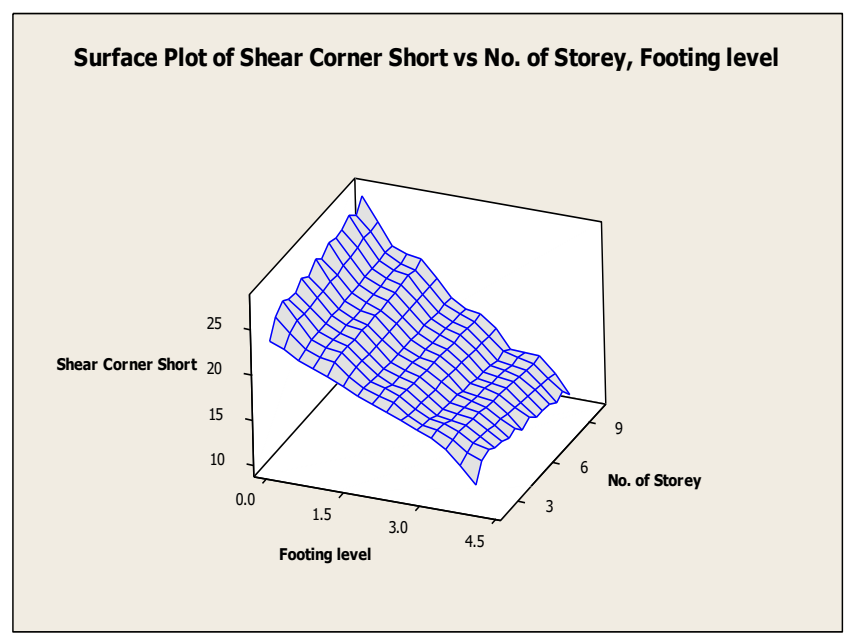

f) Shear in corner short column

Fig. 3 Shear and bending moments.

All plots show that there are linear relationships between number of storey, footing level and the Axial, shear and moment loads of all columns mentioned.

\section{RESULT}

To determine whether a linear relationship exists between different types of loads and the subset of regressor variables (i.e. Number of storey and the footing level), ANOVA and T tests were applied to test the significance of regression and its coefficients $(\alpha=0.05)$. All regression models testing analysis are shown in Tables (2), (3), and (4).

In all ANOVA tests, because the P-value is considerably smaller than $(\alpha=0.05)$, we reject the null hypothesis and conclude that axial loads is linearly related to either number of storey or footing level, or both. T test was also used to test hypothesis on the individual regression coefficient. Such test is useful in determining the potential value of number of storey and footing level in the regression model. Table (2) also shows the results of testing the hypothesis that the regression coefficients in each model are zero. Since all p-values are less than 0.05 , we can conclude that all coefficients are not zero and each regressor contributes in determining the axial loads.

Table (3) models were constructed by excluding the first two storeys. This exclusion was compensated by adding a correction factors to the models. These factors are shown in Table (3). In all ANOVA tests, because the P-value is considerably smaller than $(\alpha=0.05)$, we reject the null hypothesis and conclude that any bending moment is linearly related to either number of storey or footing level, or both. Table (3) also shows the results of testing the hypothesis that the regression coefficients in each model are zero using $\mathrm{T}$ test. Since all p-values are less than 0.05 , we can conclude that all coefficients are not zero and each regressor contributes in determining the moment.

Table (4) models were constructed by excluding the first two storeys and compensated by correction factor same as moment analysis. These factors are shown in Table (4). In all ANOVA tests, because the P-value is considerably smaller than $(\alpha=$ 0.05 ), we reject the null hypothesis and conclude that any shear load is linearly related to either number of storey or footing level, or both. Table (4) also shows the results of testing the hypothesis that the regression coefficients in each model are zero using T test. Since all p-values are less than 0.05 , we can conclude that all coefficients are not zero and each regressor contributes in determining the moment 
International Journal of Engineering Research and Technology. ISSN 0974-3154, Volume 13, Number 7 (2020), pp. 1671-1685

(C) International Research Publication House. https://dx.doi.org/10.37624/IJERT/13.7.2020.1671-1685

Table 2. Axial forces on columns in different storey and ground level

\begin{tabular}{|c|c|c|c|c|c|c|}
\hline \multirow[t]{2}{*}{ Formulation } & \multirow[t]{2}{*}{$\mathrm{R}^{2}$} & \multicolumn{2}{|c|}{ ANOVA Results } & \multicolumn{3}{|c|}{ T-Test Results } \\
\hline & & $f_{0}$ & $P$-value & Coefficient & to & $P$-value \\
\hline \multirow{3}{*}{$P_{e l}=-100+445 N_{s}+22.7 F_{1}$} & \multirow[t]{3}{*}{100} & \multirow[t]{3}{*}{66440.66} & \multirow[t]{3}{*}{0.000} & Constant & -11.10 & 0.000 \\
\hline & & & & No. of Storey & 364.41 & 0.000 \\
\hline & & & & Footing Level & 9.15 & 0.000 \\
\hline \multirow{3}{*}{$P_{e s}=-53.2+436 N_{s}-7.29 F_{1}$} & \multirow[t]{3}{*}{100} & \multirow[t]{3}{*}{76458.79} & \multirow[t]{3}{*}{0.000} & Constant & -6.44 & 0.000 \\
\hline & & & & No. Of Storey & 391.03 & 0.000 \\
\hline & & & & Footing Level & -3.22 & 0.002 \\
\hline \multirow{3}{*}{$P_{i l}=406+710 N_{s}-45.9 F_{1}$} & \multirow[t]{3}{*}{99.7} & \multirow[t]{3}{*}{8732.70} & \multirow[t]{3}{*}{0.000} & Constant & 10.19 & 0.000 \\
\hline & & & & No. Of Storey & 132.09 & 0.000 \\
\hline & & & & Footing Level & -4.21 & 0.000 \\
\hline \multirow{3}{*}{$P_{i s}=155+756 N_{s}+35.2 F_{1}$} & \multirow[t]{3}{*}{99.8} & \multirow[t]{3}{*}{13965.01} & \multirow[t]{3}{*}{0.000} & Constant & 4.62 & 0.000 \\
\hline & & & & No. Of Storey & 167.08 & 0.000 \\
\hline & & & & Footing Level & 3.84 & 0.000 \\
\hline \multirow[t]{3}{*}{$P_{c l}=-156+263 N_{s}+26.2 F_{1}$} & \multirow[t]{3}{*}{99.6} & \multirow[t]{3}{*}{5648.73} & \multirow[t]{3}{*}{0.000} & Constant & -8.50 & 0.000 \\
\hline & & & & No. Of Storey & 106.16 & 0.000 \\
\hline & & & & Footing Level & 5.20 & 0.000 \\
\hline \multirow[t]{3}{*}{$P_{c s}=-94.6+252 N_{s}-5.2 F_{1}$} & \multirow[t]{3}{*}{99.7} & \multirow[t]{3}{*}{7434.06} & \multirow[t]{3}{*}{0.000} & Constant & -6.17 & 0.000 \\
\hline & & & & No. Of Storey & 121.93 & 0.000 \\
\hline & & & & Footing Level & -1.24 & 0.220 \\
\hline
\end{tabular}

Table 3. Bending moments on short columns in different storey and ground level

\begin{tabular}{|c|c|c|c|c|c|c|}
\hline \multirow[t]{2}{*}{ Formulation } & \multirow[t]{2}{*}{$\mathrm{R}^{2}$} & \multicolumn{2}{|c|}{ ANOVA Results } & \multicolumn{3}{|c|}{ T-Test Results } \\
\hline & & $\overline{f_{0}}$ & $P$-value & Coefficient & to & $P$-value \\
\hline \multirow[t]{3}{*}{$M_{e s}=106+0.367 N_{s}-5.16 F_{1}$} & \multirow[t]{3}{*}{97.4} & \multirow[t]{3}{*}{732.50} & \multirow[t]{3}{*}{0.000} & Constant & 167.06 & 0.000 \\
\hline & & & & No. of Storey & 4.39 & 0.000 \\
\hline & & & & Footing Level & -38.02 & 0.000 \\
\hline \multirow[t]{3}{*}{$\mathrm{M}_{\mathrm{is}}=7.93-0.346 \mathrm{~N}_{\mathrm{s}}+4.89 \mathrm{~F}_{1}$} & \multirow[t]{3}{*}{97.1} & \multirow[t]{3}{*}{664.52} & \multirow[t]{3}{*}{0.000} & Constant & 12.49 & 0.000 \\
\hline & & & & No. Of Storey & -4.16 & 0.000 \\
\hline & & & & Footing Level & 36.22 & 0.002 \\
\hline \multirow[t]{3}{*}{$M_{c s}=52.9+0.202 N_{s}-4.25 F_{1}$} & \multirow[t]{3}{*}{97.8} & \multirow[t]{3}{*}{854.72} & \multirow[t]{3}{*}{0.000} & Constant & 109.14 & 0.000 \\
\hline & & & & No. Of Storey & 3.17 & 0.003 \\
\hline & & & & Footing Level & -41.22 & 0.000 \\
\hline
\end{tabular}


Table 4. Shear force on columns in different storey and ground level

\begin{tabular}{|c|c|c|c|c|c|c|}
\hline \multirow[t]{2}{*}{ Formulation } & \multirow[t]{2}{*}{$\mathrm{R}^{2}$} & \multicolumn{2}{|c|}{ ANOVA Results } & \multicolumn{3}{|c|}{ T-Test Results } \\
\hline & & $f_{0}$ & $P$-value & Coefficient & to & $P$-value \\
\hline \multirow{3}{*}{$S_{\text {es }}=53.1-0.0526 \mathrm{Ns}-4.32 \mathrm{Fl}$} & \multirow[t]{3}{*}{97.2} & \multirow[t]{3}{*}{666.53} & \multirow[t]{3}{*}{0.000} & Constant & 95.42 & 0.000 \\
\hline & & & & No. of Storey & -0.72 & 0.476 \\
\hline & & & & Footing Level & -36.50 & 0.000 \\
\hline \multirow[t]{3}{*}{$S_{\text {is }}=8.26-0.750 \mathrm{~N} s-1.84 F l$} & \multirow[t]{3}{*}{92.9} & \multirow[t]{3}{*}{255.83} & \multirow[t]{3}{*}{0.000} & Constant & 18.00 & 0.000 \\
\hline & & & & No. Of Storey & -12.45 & 0.000 \\
\hline & & & & Footing Level & 18.88 & 0.002 \\
\hline \multirow[t]{3}{*}{$S_{\mathrm{cs}}=27.1-0.134 \mathrm{~N} s-3.83 F l$} & \multirow[t]{3}{*}{97.5} & \multirow[t]{3}{*}{768.25} & \multirow[t]{3}{*}{0.000} & Constant & 58.85 & 0.000 \\
\hline & & & & No. Of Storey & -2.26 & 0.029 \\
\hline & & & & Footing Level & -39.20 & 0.000 \\
\hline
\end{tabular}

\section{Notation:}

$\mathrm{P}_{\mathrm{el}}=$ Axial edge long $\quad \mathrm{P}_{\mathrm{es}}=$ Axial edge short $\quad \mathrm{P}_{\mathrm{il}}=$ Axial internal long

$\mathrm{P}_{\mathrm{is}}=$ Axial internal short $\quad \mathrm{P}_{\mathrm{cl}}=$ Axial corner long $\mathrm{P}_{\mathrm{cs}}=$ Axial corner short

$\mathrm{M}_{\mathrm{es}}=$ Moment edge short $\quad \mathrm{M}_{\mathrm{is}}=$ Moment internal short $\quad \mathrm{M}_{\mathrm{cs}}=$ Moment corner short

$\mathrm{S}_{\text {es }}=$ Shear edge short $\quad \mathrm{S}_{\text {is }}=$ Shear internal short $\quad \mathrm{S}_{\mathrm{cs}}=$ Shear corner short

$\mathrm{N}_{\mathrm{s}}=$ Number of storey $\quad \mathrm{F}_{1}=$ Footing level

\section{DISCUSSION}

The three-dimensional linear analysis has been carried out using SAP2000 to study the behaviour of columns under different ground levels and different numbers of storeys. The behaviour of columns includes axial force, shear force, and bending moment. All the results have been taken for the columns at the ground level when the phenomenon of the short column has appeared. Then the suggestion equation has been established by using multiple linear regressions (MLR) by Minitab program.

\section{IV.I Axial Forces on Column}

Figures $4 \mathrm{a}$ through $4 \mathrm{f}$ show the axial forces in columns with varying storey and ground levels. From the figures can be noticed the axial force for all types of columns increases as the number of stories in the building increases at the same ground level. This event is logical since increasing the number of stories will increase the load that should be carried by each column.

On the other hand, it's obviously shown from figures 5a and $5 \mathrm{~b}$; for the same footing level and number of stories the axial force resulted in the internal short columns and long columns is larger than the edge short columns and the corner ones respectively which is very common due to the tributary area surrounded by each column.

\section{II Comparison between Short and Long Columns}

Figures 6 a through $6 \mathrm{c}$ show the comparing of axial forces in columns with ground level at $4 \mathrm{~m}$ as a typical case.
Comparing the results of short and long columns, regarding the axial force, the following points are clearly noticed.

- The edge and corner long columns take higher loads than the short columns, the variation in the value of the axial force starts to be significant as the number of stories and the footing levels are getting higher.

- Short internal columns take a higher portion of the load as their axial stiffness is larger than the long columns due to having shorter height and this variation is considerable especially with higher footing levels and higher stories.

- The other fact about the edge and corner columns could be considered weird at first. Although it makes a lot of sense as the analysed building in the model is symmetry so that the load will be divided perfectly by two in order not to overturn and remain stable. This means if the short internal columns take a higher portion of the load a lower portion is remaining for the short edge and corner ones and the exact opposite is happing in the long columns half. 


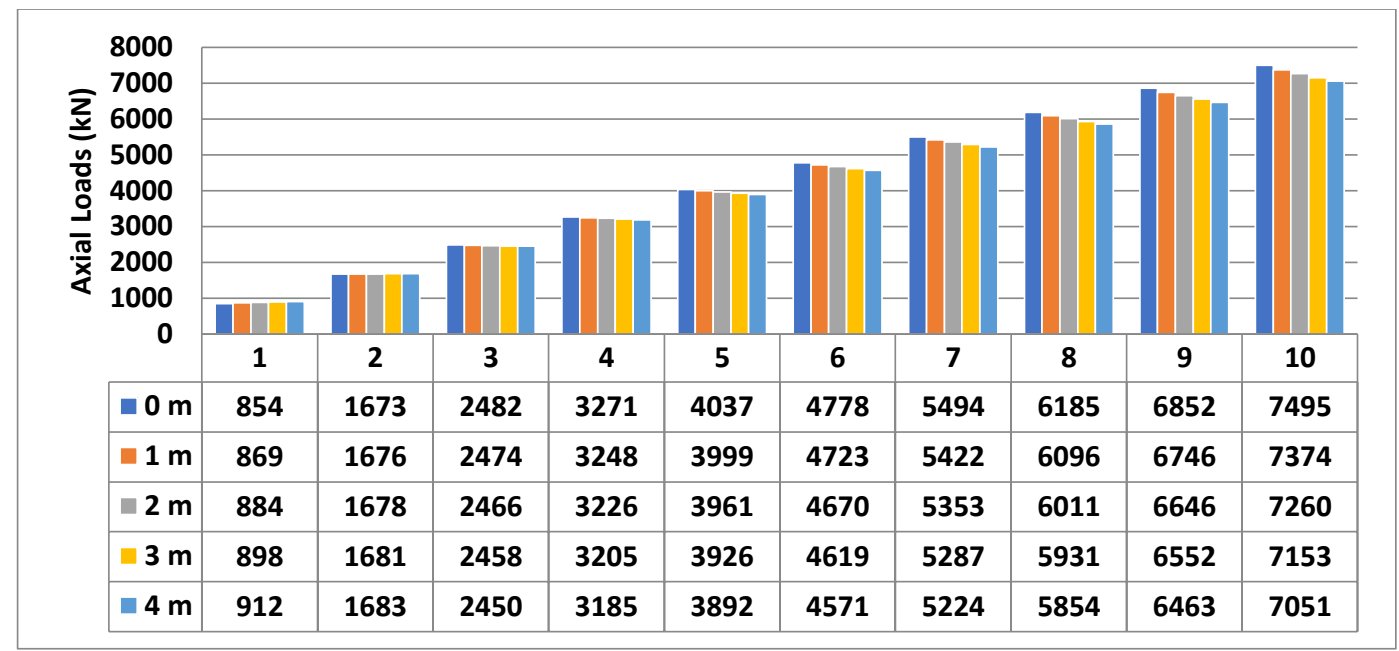

a) Internal long column

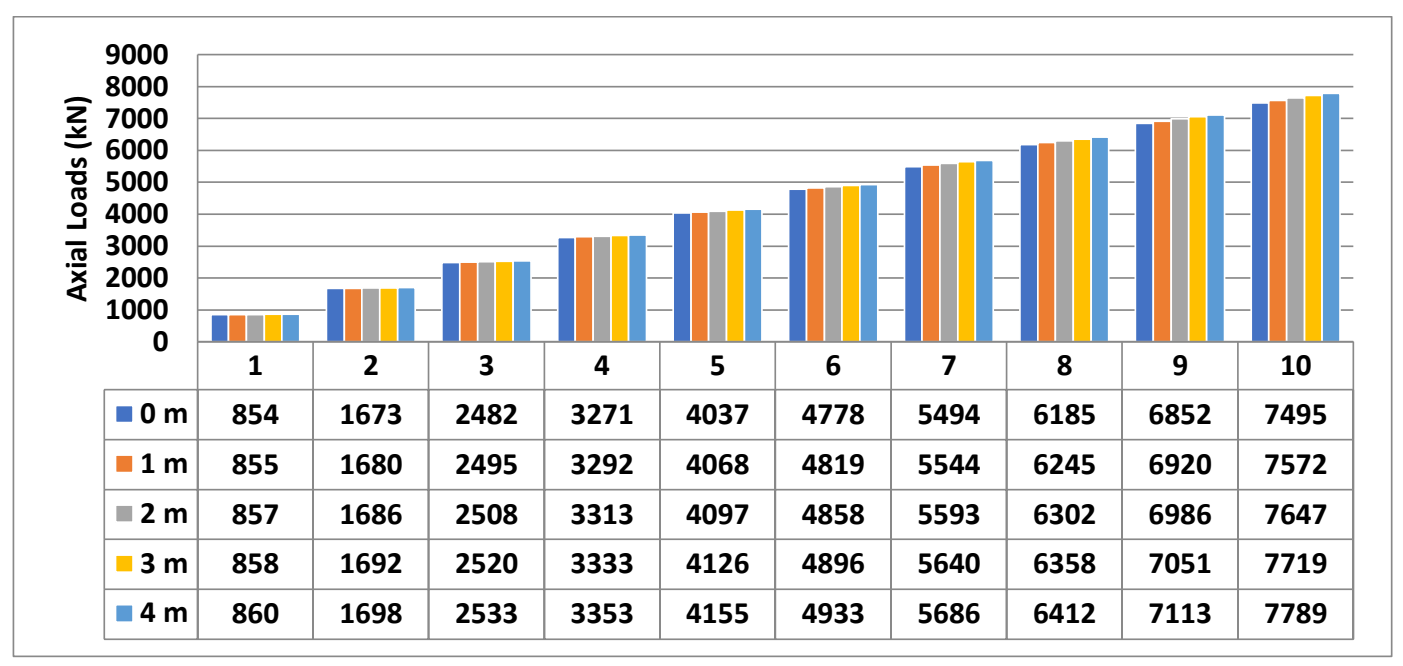

b) Internal short column

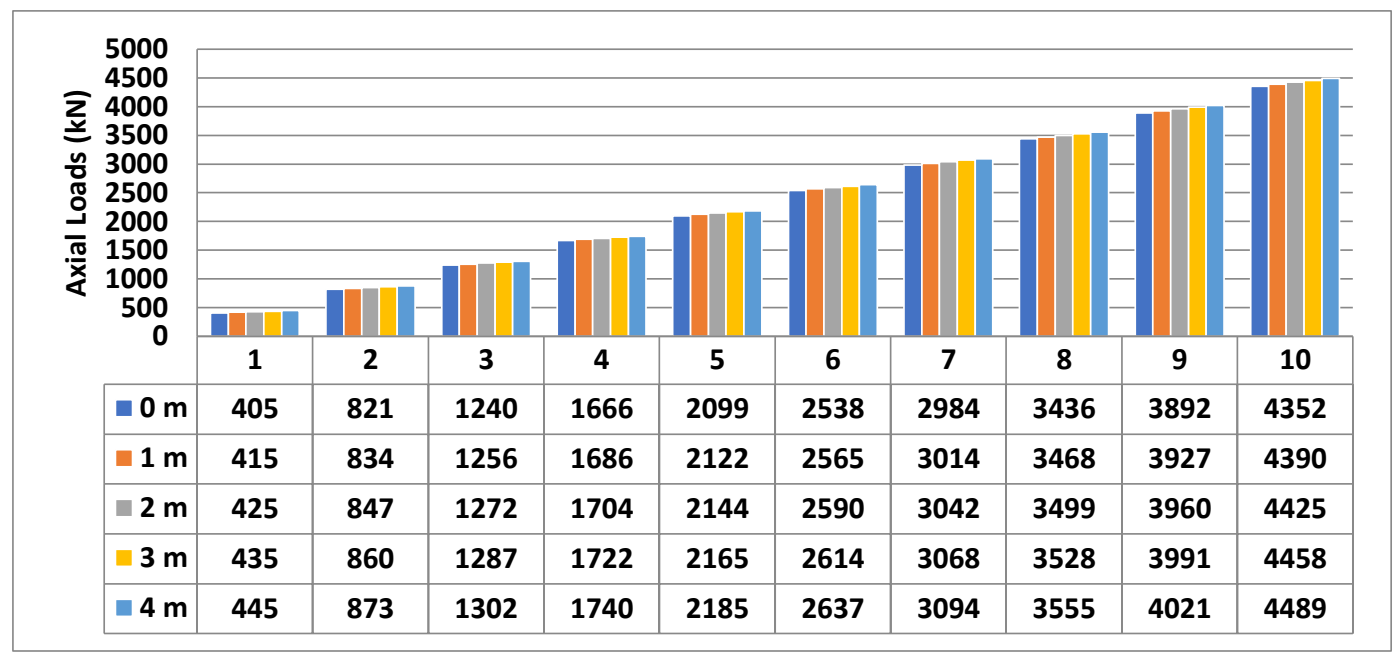

c) Edge long column 


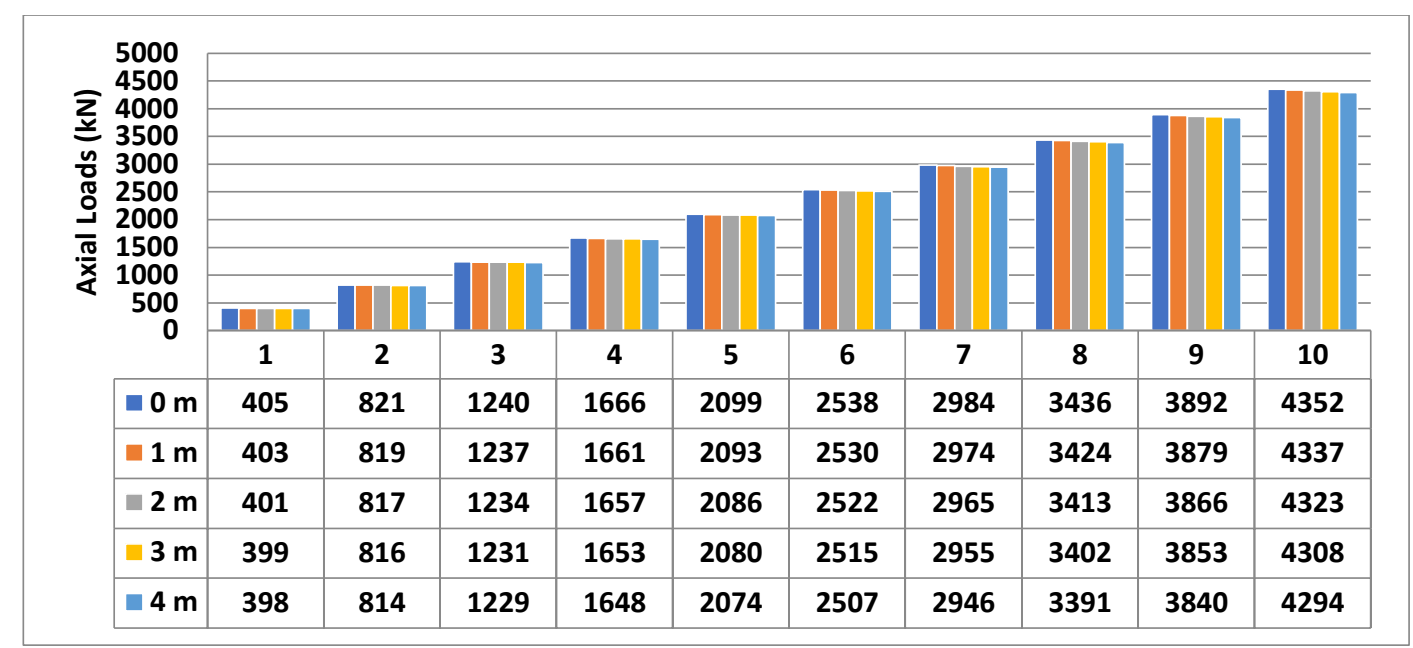

d) Edge short column

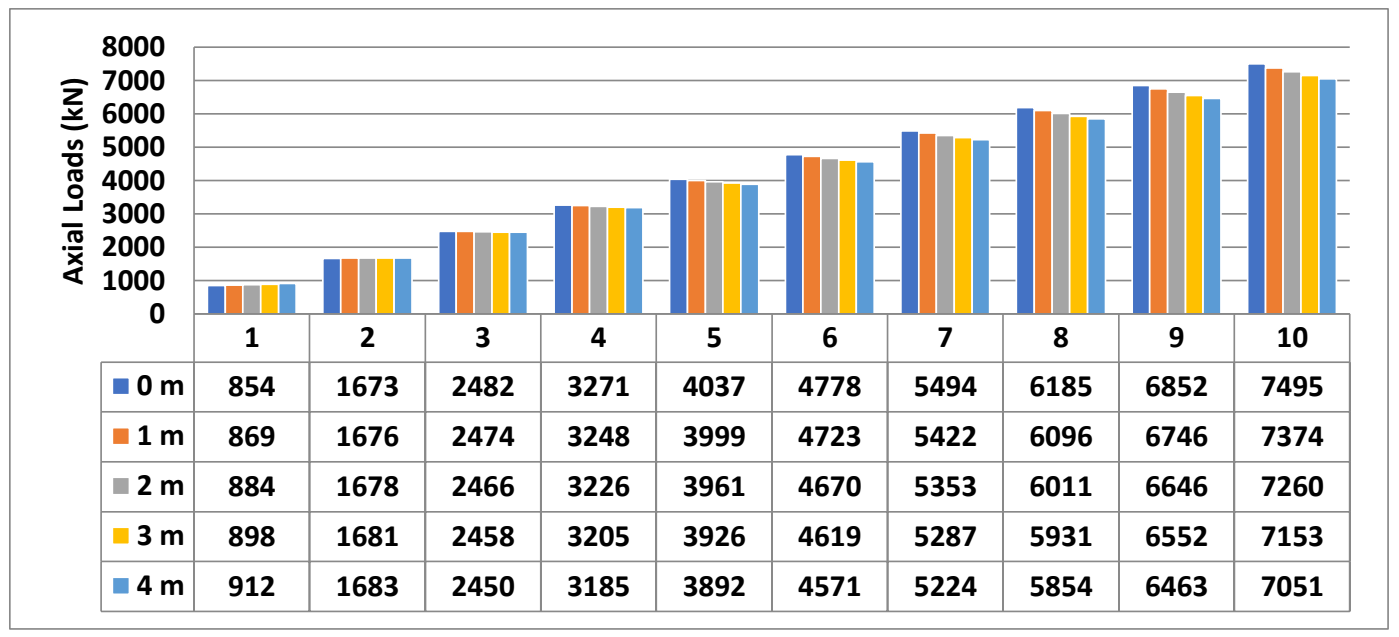

e) Corner long column

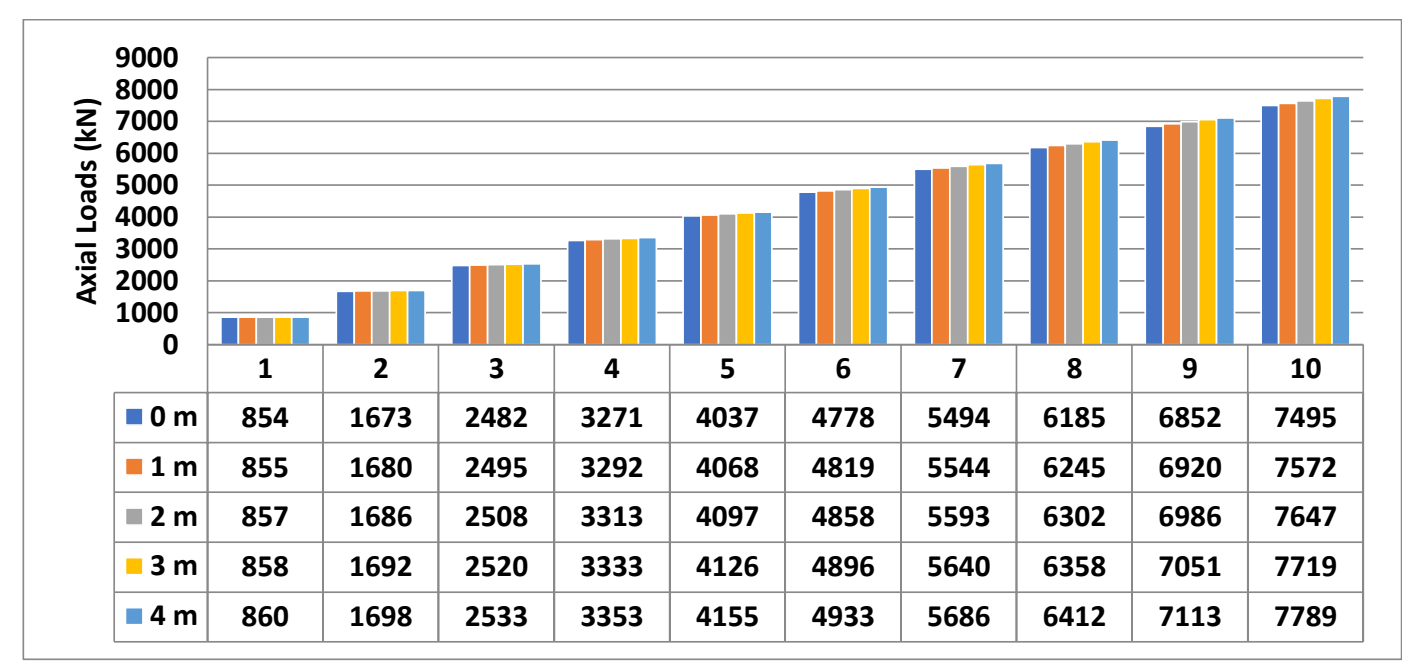

f) Corner short column

Fig. 4 Column axial forces with different storey and ground levels 


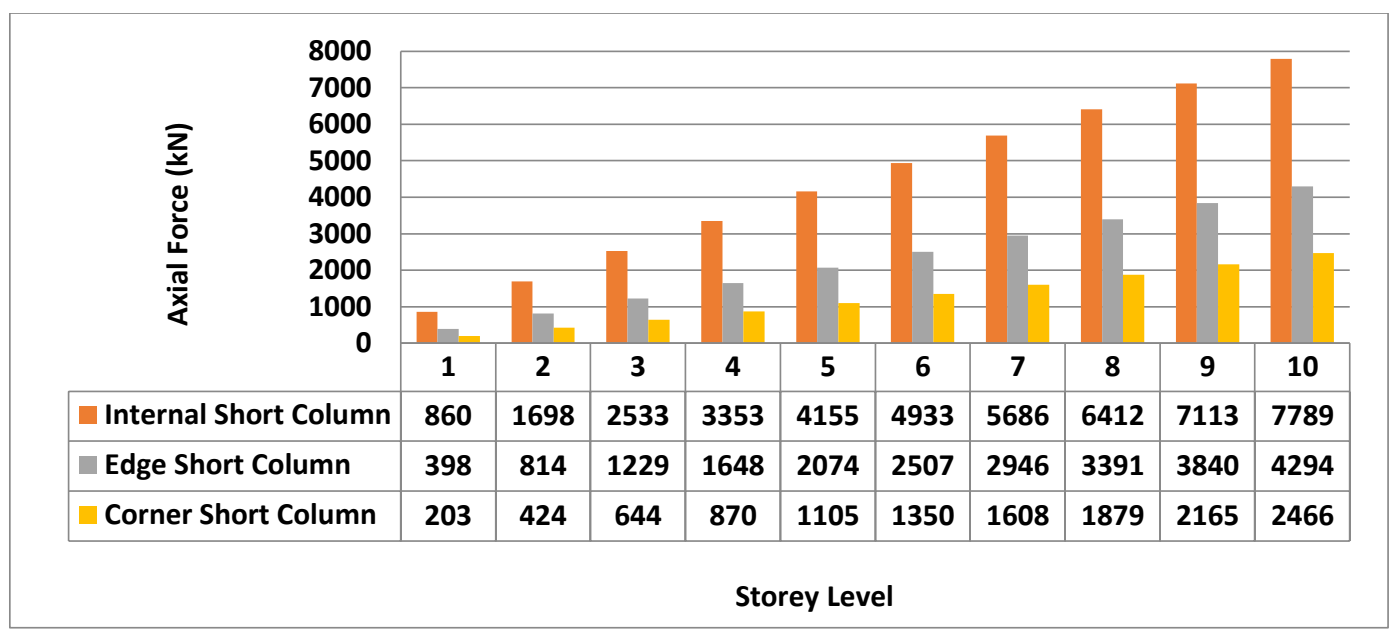

a) Short column (Internal, Edge, Corner)

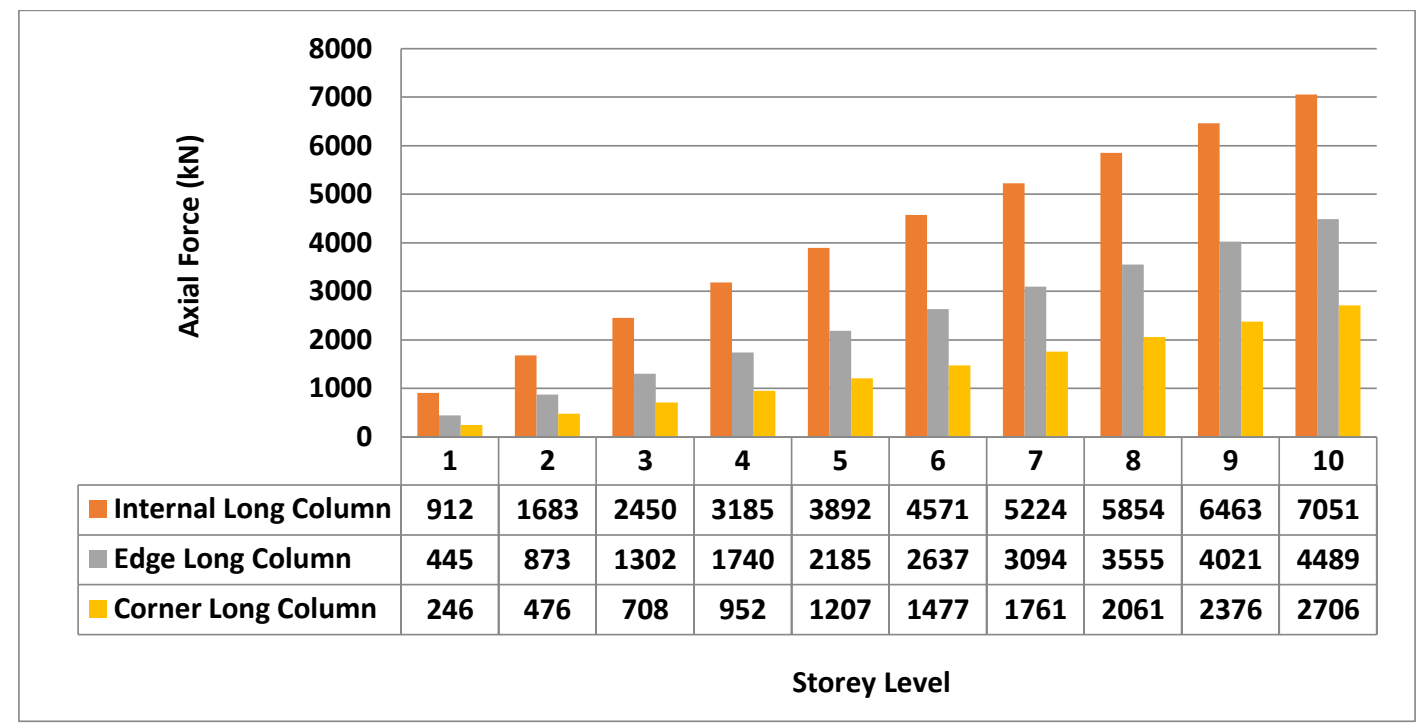

b) Long column (Internal, Edge, Corner)

Fig. 5 Column axial forces at ground level $4 \mathrm{~m}$ as a typical case

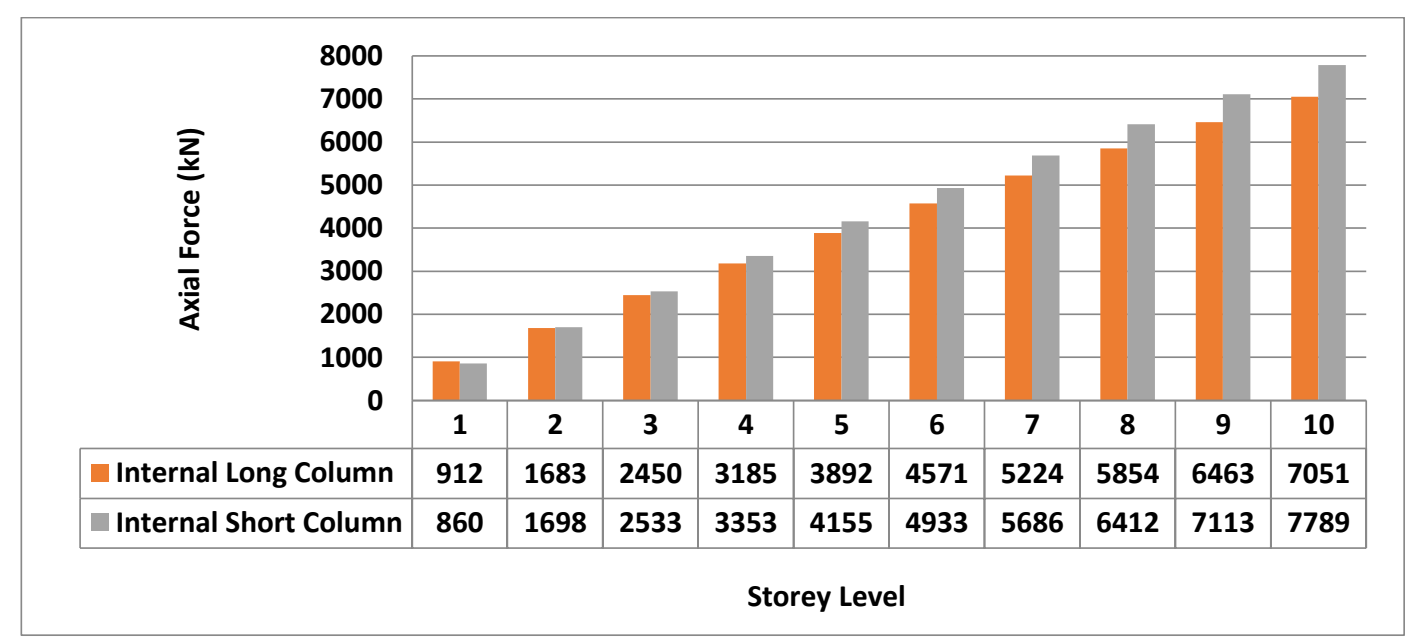

a) Internal (Long column, Short column) 


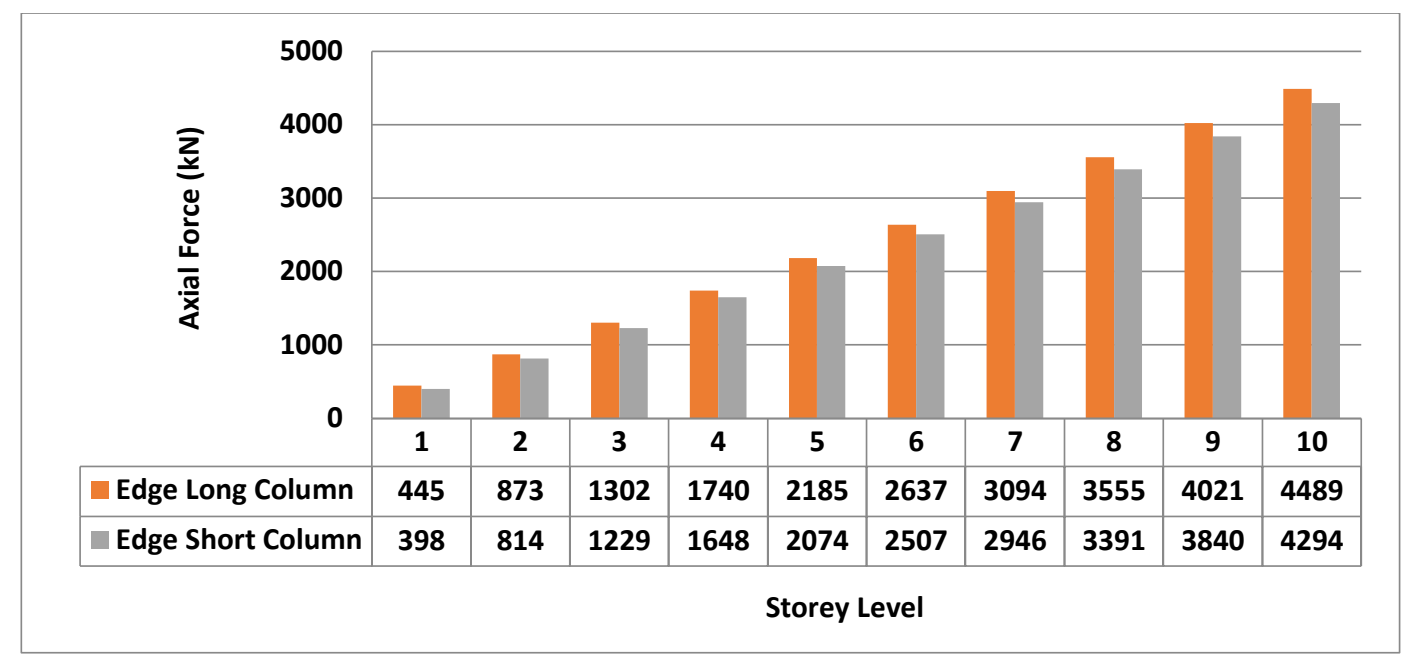

b) Edge (Long column, Short column)

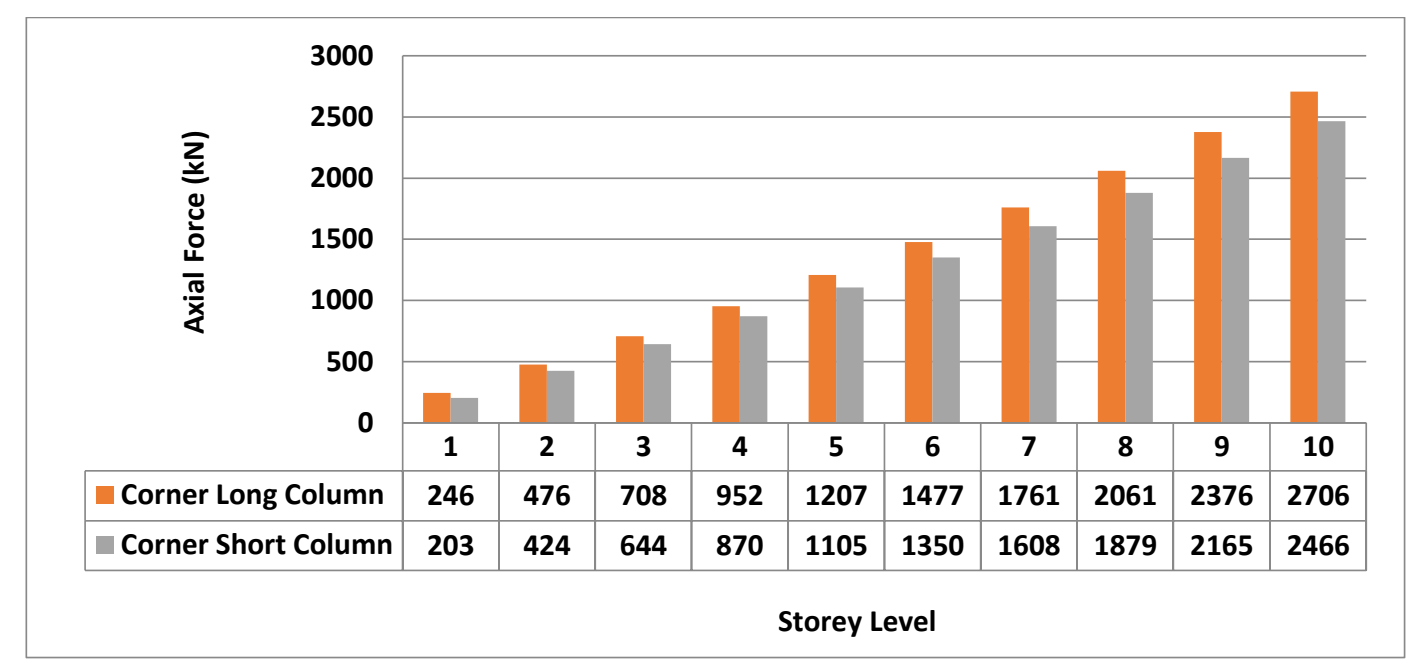

c) Corner (Long column, Short column)

Fig. 6 Comparison of axial forces on columns at ground level $4 \mathrm{~m}$ as a typical case

\section{IV.III Shear and Bending Moments on Column}

Figures 7 through 8 show the shear and bending moments in different position of short columns, ground level, and different storey levels. From the figures can be noticed clearly:

- $\quad$ Edge short column takes more moment and shear compared to the corner and internal ones respectively.

- The effect of changing the number of floors with the same value of ground level is not significant in shear and moment for all types of columns except for the one-storey and twostorey buildings. to illustrate more, the moment and shear for a building contains one storey is very high compared to the two-storey building where the value becomes significantly low; then getting higher again with a 3 -storey building and with more stories.
- The varying the ground level with the same number of stories increases the value of shear and moment resulted in the internal short column whereas the exact opposite happens with the edge and corner ones. The previous observations can be justified as the following. For the first point, edge columns take higher portion of the internal load than the others since they have an odd number of sides which means that some internal forces will not be cancelled as it happens with the internal column that has four sides. Regarding the second point, the significant increase with a one-storey building is reasonable due to the fact that there is no other column exists to take these internal forces. In addition, the joint between the beam and column is not that rigid especially when it is compared with the fixed support downward as it can be seen in the model. Moreover, the major decrease in the shear and moment for the two-storey building is also illustrated, since the connection contains in this case two columns and it could be concerned Simi-rigid. However, for a three-storey building and a multiple story building the same trend is expressed as 
International Journal of Engineering Research and Technology. ISSN 0974-3154, Volume 13, Number 7 (2020), pp. 1671-1685

(C) International Research Publication House. https://dx.doi.org/10.37624/IJERT/13.7.2020.1671-1685

the joint becomes more- fixed and for the first floor column where the reading is being taken there will be no significant difference from now on in the value of shear and moment regarding the number of stories.

- Finally, the increment in the value of the shear and moment in short internal columns could be understood by the fact that these columns are very important since they are surrounded by four sides and due to the fact that their stiffness is getting higher as their height is getting smaller compared to the long ones so that increasing the footing level will cause an increase in the value of internal forces in these columns. Moreover, since the building is perfectly symmetry the load in general is divided by two. As a result, the increment in the shear and moment values for internal columns will cause a decrement in the values of shear and moment for the other two types of columns in the short half of the building.

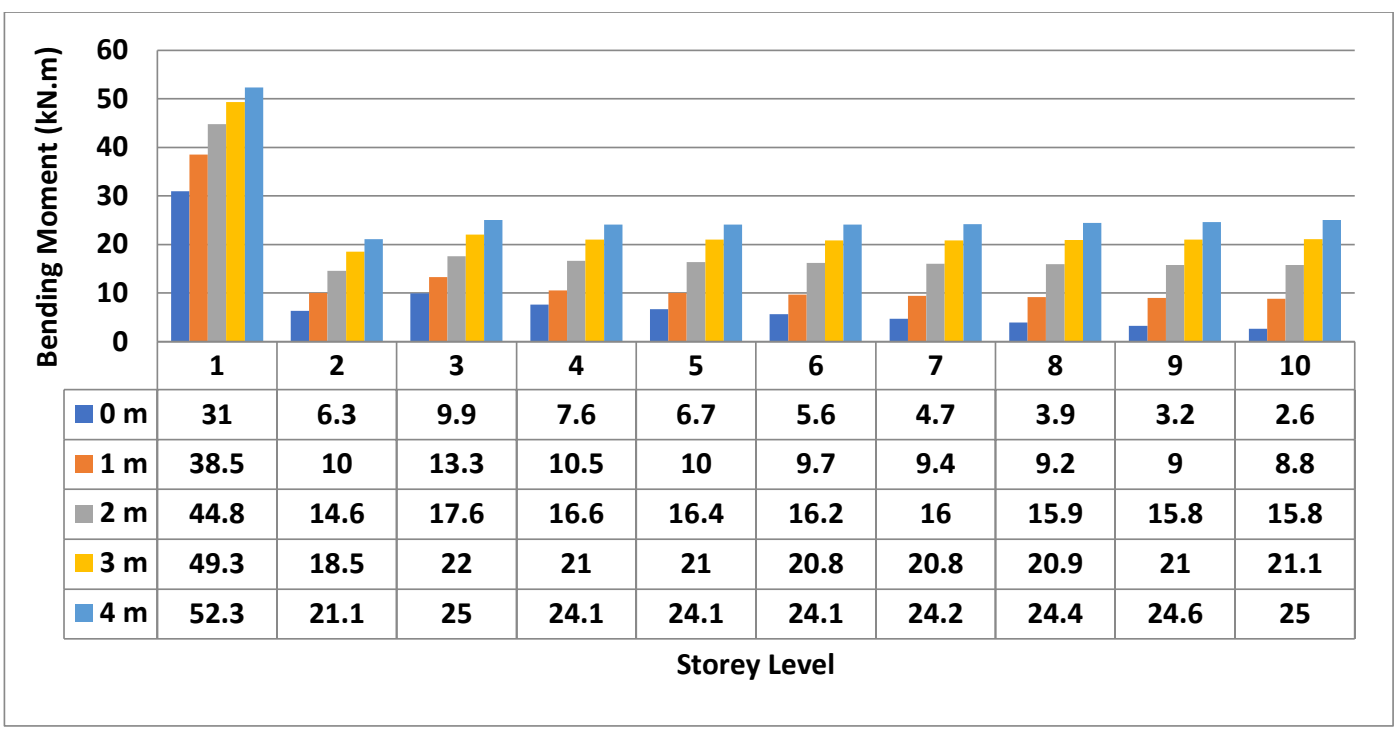

a) Internal column

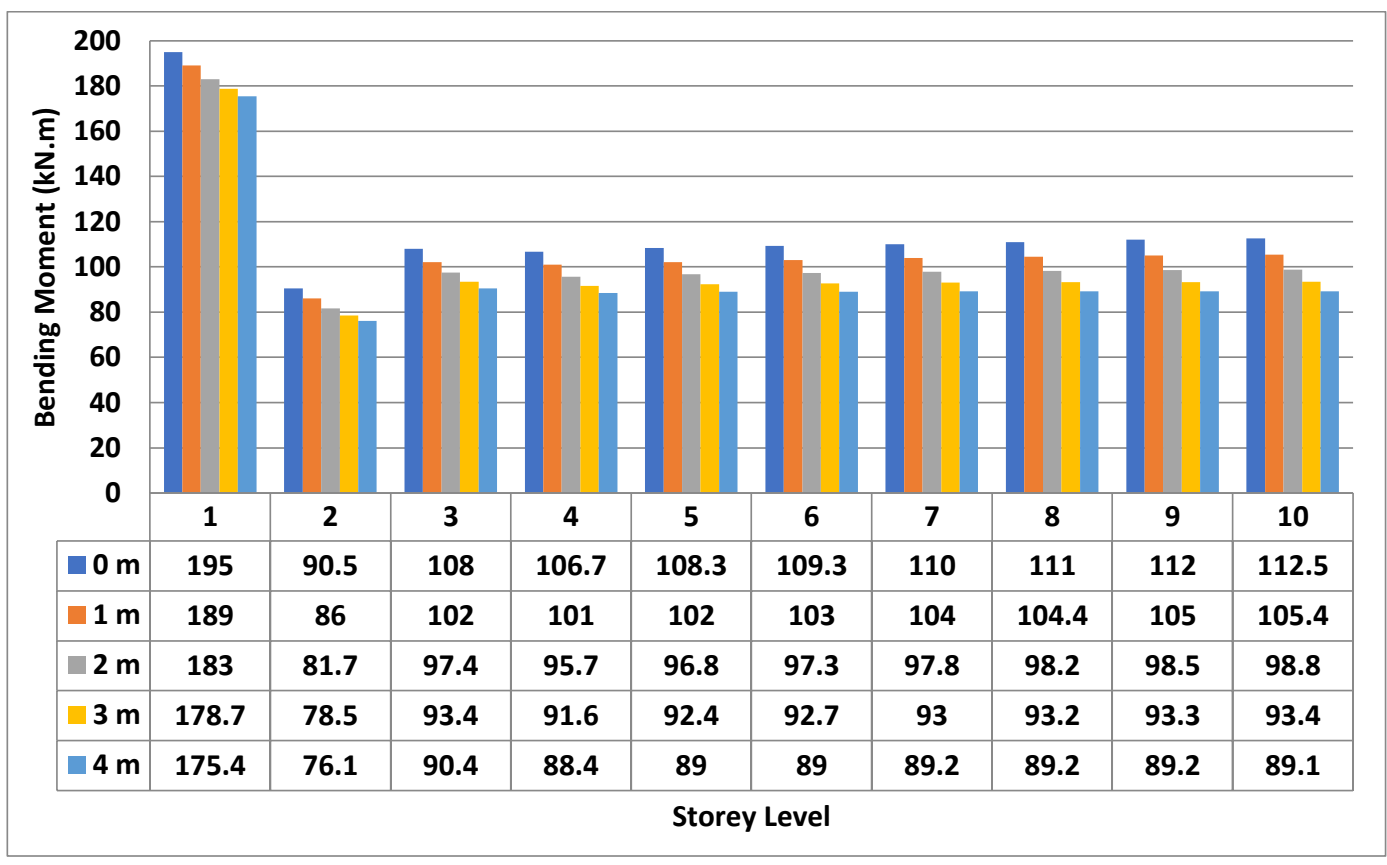

b) Edge column 


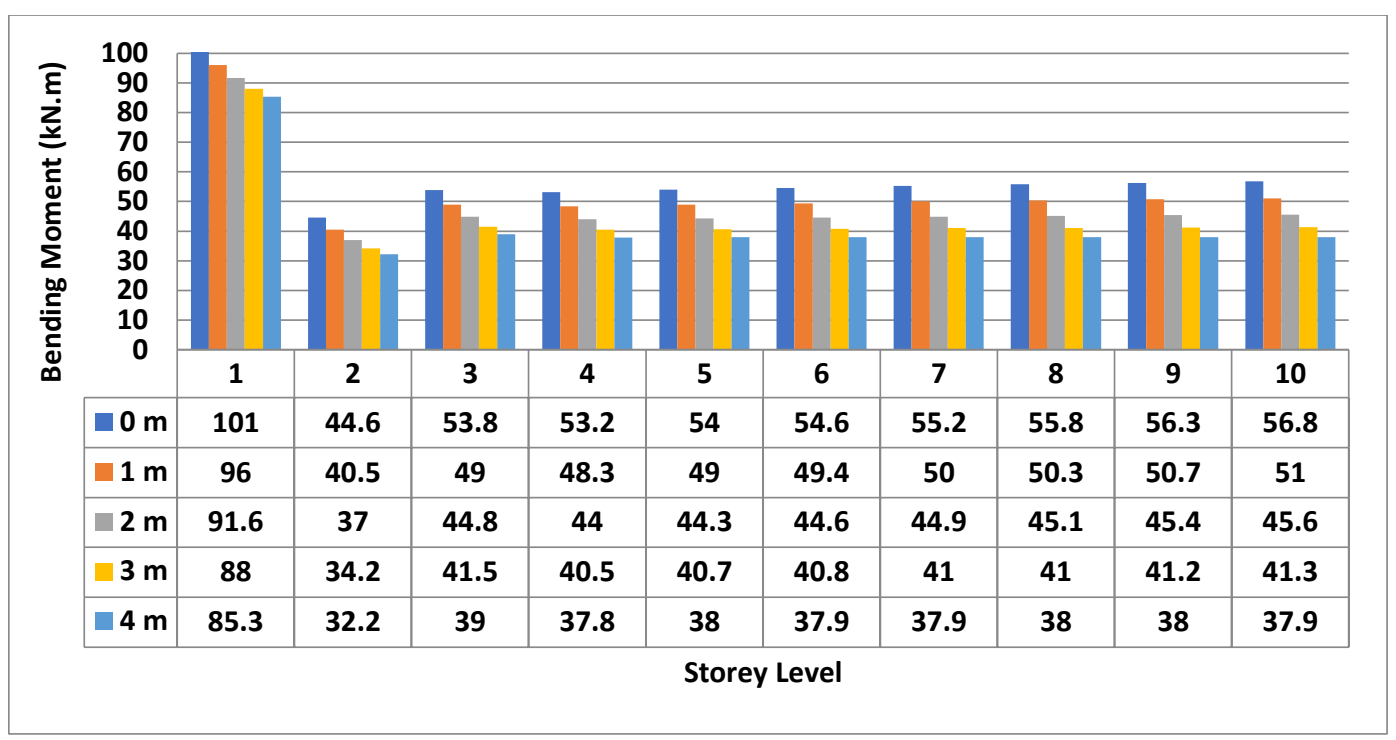

c) Corner column

Fig.7 Short column bending moments at different footing level 1 to 4

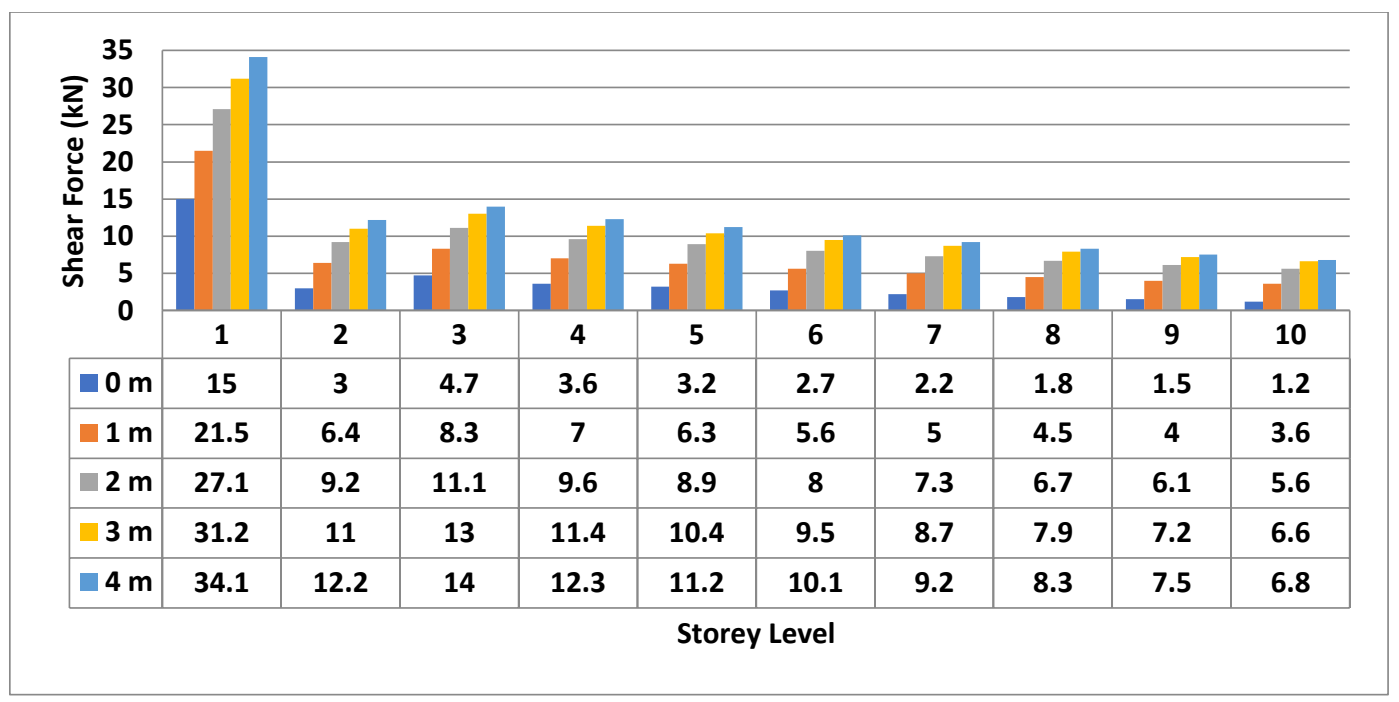

a) Internal column

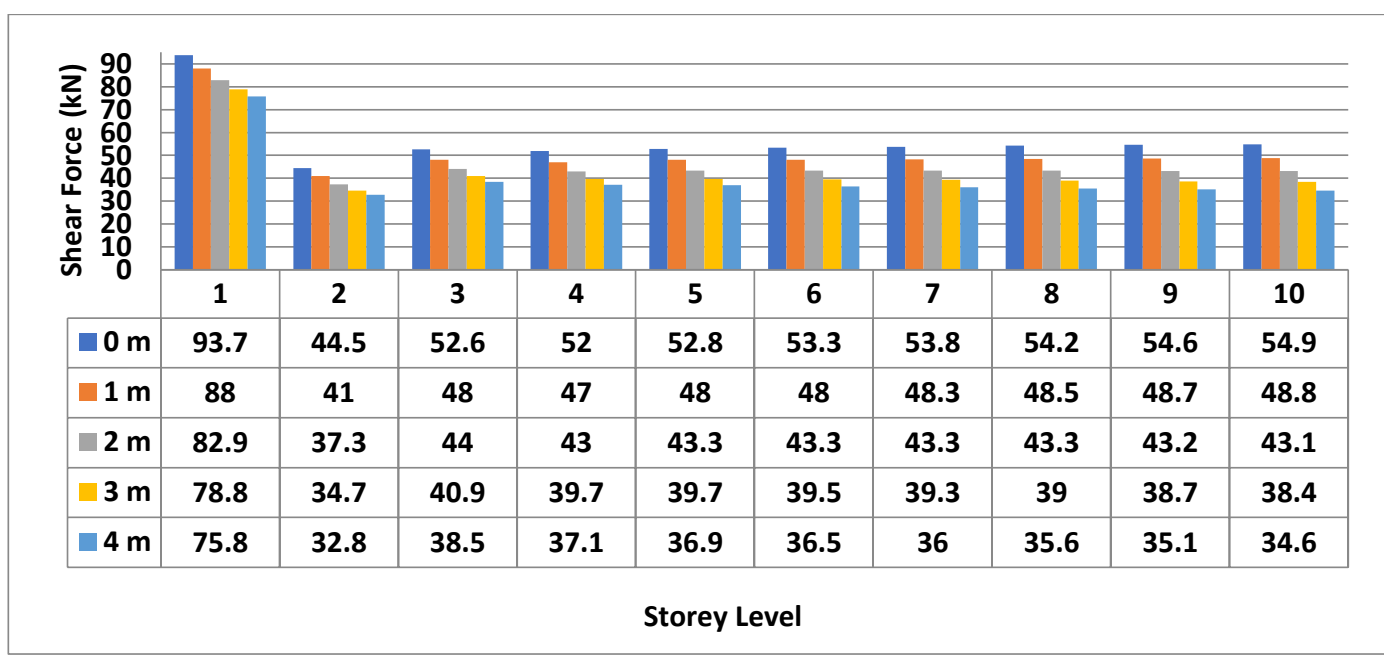

b) Edge column 


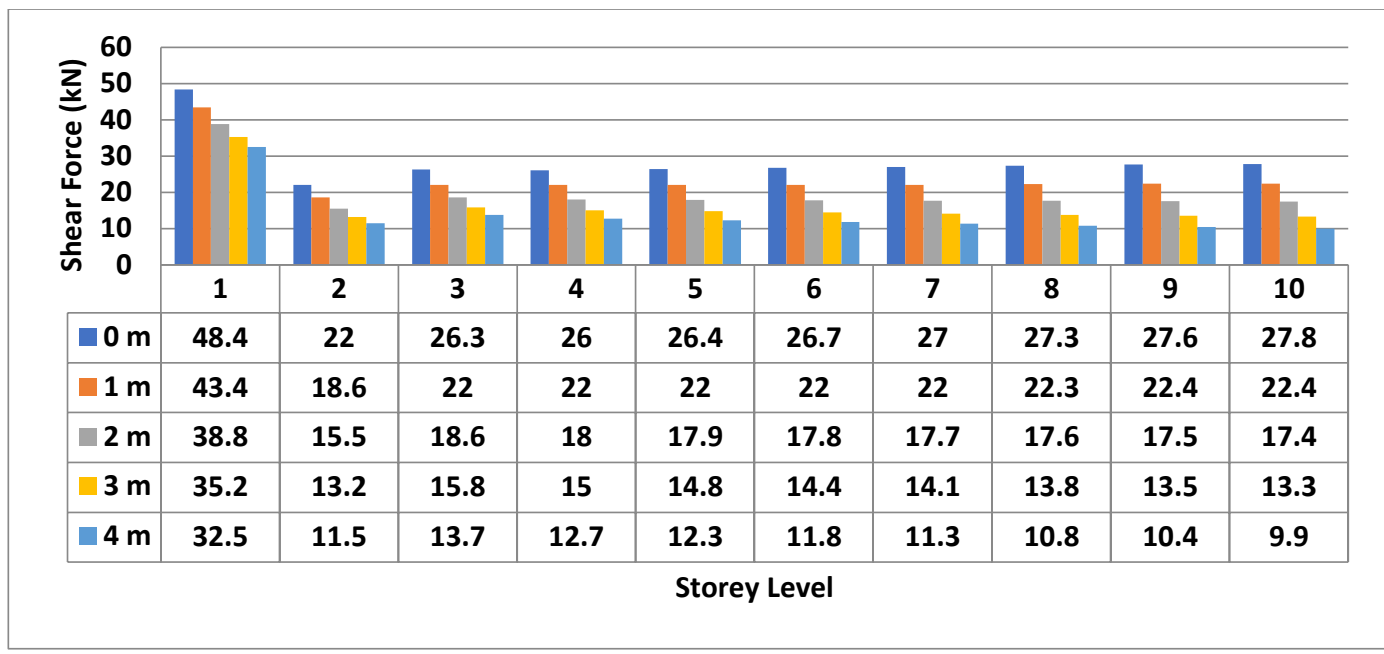

c) Corner column

Fig. 8 Short column shear forces at different footing level 1 to 4

\section{CONCLUSION}

The 3D finite element method and regression analysis presented in this paper lead to more information on the behaviour of short columns due to the varying of ground level and storey levels.

The main point that should be stressed out to sum up the difference in the axial behaviour between these two types of columns is that; if the designer is intended to build a low rise building with a lower variation in the ground level no actual significance is noticed and this is clear in the derived equations. However, for high rise buildings and higher variation in the ground levels special care should be taken into account as there will be significance in the designing values between short and long columns.

On the other hand, the increment in the value of the shear and moment in short internal columns could be understood by the fact that these columns are very important since they are surrounded by four sides and due to the fact that their stiffness is getting higher as their height is getting smaller compared to the long ones so that increasing the footing level will cause an increase in the value of internal forces in these columns. Moreover, since the building is perfectly symmetry the load in general is divided by two. As a result, the increment in the shear and moment values for internal columns will cause a decrement in the values of shear and moment for the other two types of columns in the short half of the building.

\section{REFERENCES}

[1]. Raj, D., Y. Singh, and A. Kaynia. (2018). Behaviour of slopes under multiple adjacent footings and buildings, International Journal of Geomechanics, ASCE, 18 (7), 1-28.

[2]. Ghosh, R., and Debbarma, R. (2019). Effect of slope angle variation on the structures resting on hilly region considering soil-structure interaction, International Journal of Advanced Structural Engineering, 11, 6777.

[3]. Ghosh, R, and Debbarma, R. (2017). Performance evaluation of setback buildings with open ground storey on plain and sloping ground under earthquake loadings and mitigation of failure, Int. J. Adv. Struct. Eng., vol. 9, no. 2, 97-110.

[4]. Rabbany, A. B. M., Islam, A., Zaman, H. (2018). Short RCC Column Performances in Different Conditions: Axial, Uniaxial \& Biaxial Bending, Journal of Civil Engineering Research, 8(3), 70-85.

[5]. Pokharel, T., and Goldsworthy, H. M. (2015). Lessons learned from the Nepal earthquake 2015, In: Proceedings of the 10th Pacific Conference on Earthquake Engineering Building an Earthquake Resilient Pacific. Sydney.

[6]. Lu, Y. Q., Huang, L., Xu, Z. P., and Yin, P. (2015). Strength envelope of symmetrically reinforced concrete members under bending-shear-axial loads, Mag. Concr. Res., 67(16), 885-896.

[7]. Abdelwahed, B. S., Belkassem, B., and Vantomme, J. (2018). Reinforced concrete beam-column inverted knee joint behaviour after ground corner column lossnumerical analysis, Latin American Journal of Solids and Structures 15(10): 1-15

[8]. Ramin, K., and Mehrabpour, F. (2014). Study of Short Column Behavior Originated from the Level Difference on Sloping Lots during Earthquake (Special Case: Reinforced Concrete Buildings), Open Journal of Civil Engineering, Vol. 4, 23-34.

[9]. Singh, Y., Gade, P., Lang, DH., Erduran, E. (2012). Seismic Behaviour of Buildings Located on SlopesAn Analytical Study and Some Observations from Sikkim Earthquake of 18th September 2011, The 15th 
World Conference on Earthquake Engineering, Lisbon, Portugal.

[10]. Mohammad, Z., Baqi, A., Arif, M. (2017). Seismic response of RC framed buildings resting on hill slopes. In the Proceedings of 11th International Symposium on Plasticity and Impact Mechanics, Implast, Dec. 11 to 14, 2016. Procedia Engineering, 173, 1792-99.

[11]. BONO, G. F. F., CAMPOS F. A., PACHECO, A. R. A. (2011). 3D finite element model for reinforced concrete structures analysis. IBRACON Structural Journal, SP, v. 4, 548-560.

[12]. Fu, F. (2010). 3-D nonlinear dynamic progressive collapse analysis of multi-storey steel composite frame buildings-Parametric study, Eng Struct, 32(12), 3974-3980.

[13]. Shan, S., Li, S., Xu, S., Xie, L. (2016). Experimental study on the progressive collapse performance of RC frames with infill walls, Eng Struct, 111,80-92.

[14]. Caldas, R. B., Fakury, R. H. and Sousa Jr., J. B. M. (2014). Finite element implementation for the analysis of 3D steel and composite frames subjected to fire, Latin American Journal of Solids and Structures, Vol. 11, 001-018.

[15]. Siu, M., Ekyalimpa, R., Lu, M., Abourizk, S. (2013). Applying Regression Analysis to Predict and Classify Construction Cycle Time, Computing in Civil Engineering, ASCE,669-676.

[16]. Egbe, J. G., Ewa, D. E., Ubi, S. E., Ikwa, G. B., \& Tumenayo, O. O. (2018). Application of multilinear regression analysis in modeling of soil properties for geotechnical civil engineering works in Calabar South. Nigerian Journal of Technology, 36(4), 1059. doi:10.4314/njt. v36i4.10

[17]. Islam, M. S., \& Alam, S. (2013). Principal Component and Multiple Regression Analysis for Steel Fiber Reinforced Concrete (SFRC) Beams. International Journal of Concrete Structures and Materials, 7(4), 303-317. doi:10.1007/s40069-013-0059-7

[18]. Liu, S., Ding, X., Li, X., Liu, Y., \& Zhao, S. (2019). Behavior of Rectangular-Sectional Steel Tubular Columns Filled with High-Strength Steel Fiber Reinforced Concrete Under Axial Compression. Materials, 12(17), 2716. doi:10.3390/ma12172716

[19]. Arshadi, H., Kheyroddin, A. (2019). Shear lag phenomenon in the tubular systems with outriggers and belt trusses. Magazine of Civil Engineering. 86(2), 105-118

[20]. Irawan R, Priyosulistyo H, Suhendro B (2014) Evaluation of forces on a steel truss structure using modified resonance frequency. Proc Eng 95:196-203 